\title{
Escherichia coli and Serratia fonticola ESBLs as a potential source of antibiotics resistance dissemination in the Tricity water reservoirs*
}

\author{
Bartosz Rybak, Natalia Wawrzyniak, Lidia Wolska and Marta Potrykus ${ }^{\circledR}$ \\ Department of Environmental Toxicology, Faculty of Health Sciences with Institute of Maritime and Tropical Medicine, Medical University of \\ Gdansk, Gdańsk, Poland
}

\begin{abstract}
Despite the fact that cephalosporins are rarely used in medical or veterinary treatment, the presence of Enterobacterales strains resistant to this group of anti-bacterial drugs (ESBL) is an important issue that requires attention. Between 2019 and 2021, 14 retention reservoirs, 12 streams, 3 rivers and 1 lake situated in the Tricity area (in northern Poland) were sampled for the presence of ESBL strains. Out of $\mathbf{4 0}$ water samples, characteristic growth (Escherichia coli and the KESC group) on Chromagar ESBL plates was observed for 33 samples. The average number of ESBL E. coli was $42 \pm 132 \mathrm{CFU} / 100 \mathrm{ml}$, while the KESC group was $73 \pm 147 \mathrm{CFU} / 100 \mathrm{ml}$. Out of 33 positive samples, $57 \mathrm{ESBL}$ Enterobacterales strains were isolated, of which the most abundant species were $E$. coli (13 isolates) and Serratia fonticola (23 isolates). The $E$. coli $\mathrm{ESBL}$ isolates not only showed resistance to third generation cephalosporins but also to antibiotics from other groups, such as fluoroquinolones, aminoglycosides and sulfonamides. The $S$. fonticola ESBL isolates were also found to be mainly resistant to the third generation cephalosporins, with the exception of 5 imipenem and 2 ertapenem-resistant strains. These strains presented highly diverse fingerprinting profiles, as well as significant differences in phenotypic traits helpful for survival in the environment, such as biofilm formation and motility. Moreover, biofilm formation and the swimming ability were species and temperature dependent. We confirmed the presence of highly diverse ESBL strains with multiple drug resistance patterns in the Tricity water reservoirs. This could possibly pose a threat to human health and create a suitable ground for acquiring antibiotics resistance in the natural environment.
\end{abstract}

Keywords: Multi-drug resistant strains, ESBL-beta-lactamase, freshwater microbial contamination

Received: 11 June, 2021; revised: 31 July, 2021; accepted: 02 August, 2021; available on-line: 24 Auigust, 2021

๑e-mail: marta.potrykus@gumed.edu.pl

*This paper is dedicated to Professor Wacław Tadeusz Szybalski on the 100th anniversary of his birth

Acknowledgements of Financial Support: This study was supported by a statutory research fund of the Laboratory of Environmental Toxicology, Medical University of Gdansk, Gdansk, Poland (ST-0103/07/322).

Abbreviations: AMR, antimicrobial resistance; CFU, colony forming units; ESBL, Extended-Spectrum Beta-Lactamases; DID, defined daily doses; DDS, double disk synergy test; MALDI-TOF MS, MatrixAssisted Laser Desorption/Ionization with Time Of Flight Mass Spectrometry; MICs, minimal inhibitory concentrations; OD, optical density; UPGMA, unweighted pair group method with arithmetic mean; PCA, principal component analysis

\section{INTRODUCTION}

Antibiotics have existed in the world since bacteria and fungi appeared on Earth, but people have noticed their effects relatively recently. The first potentially health-promoting use of tetracycline-containing beer was found in ancient Nubia around 350-550 BC (Kozińska et al., 2017). In 1897, Ernest Duchesne concluded that some moulds inhibit the growth of pathogenic bacteria (Duckett, 1999). The discovery of antibiotics became a turning point in the history of mankind. The "age of antibiotics" with antibiotics considered as "miracle drugs" that could fight almost any bacterial infection, began in 1928 after the discovery of penicillin by Alexander Fleming (Tan et al., 2015). Antibiotics have not only revolutionized medicine, but also had a huge impact on the socioeconomic well-being of people worldwide. Life expectancy has increased significantly, and mortality from many infectious diseases has decreased. People's productivity has increased by reducing absenteeism related to infectious diseases (Hutchings et al., 2019). The production of antibiotics and chemotherapeutic agents is growing every year (Kümmerer et al., 2009a; Kümmerer et al., 2009b). The amount of antibiotics produced in the world is measured in millions of tons per year (ECDC, 2015). Antibiotics, when administered to humans or animals, are partially metabolized and then excreted via faeces and/or urine, both in metabolically active and inactivated forms. Furthermore, waste from the pharmaceutical industry and agri-food processing is of great importance with regards to the amount of metabolites and active forms of antibiotics released into the environment. They are released to municipal and industrial wastewater, and ultimately end up in surface waters. Waste and manure from animal husbandry is used as fertilizer on arable lands. This leads to the accumulation of antibiotics in the soil of farmlands and bottom sediments of water reservoirs, where antibiotics are being washed out from the soil, run off with rainwater and penetrate into the groundwater (Kümmerer et al., 2003). Fish farms likewise can be a source of antibiotics and their residues for other water reservoirs, such as rivers, lakes or ponds. However, municipal sewage, including sewage from hospitals, is considered to be the main source of contamination with antibacterial drugs. During biological waste water treatment, bioreactors contain various active and inactive forms of antimicrobial agents and a high content of microorganisms. The concentrations of drugs at this stage of treatment can vary, but even if low, they can affect microorganisms and promote horizontal gene exchange of resistance genes (Thanner et al., 2016). Next, the an- 
tibiotic residues can be rinsed from the sewage sludge and move further, reaching rivers and the seas. While the majority of microorganisms resistant to antibiotics remains in the sludge of the sewage treatment plant, some of the drug-resistant bacteria may enter the natural environment (Galvin et al., 2010; Zhi et al., 2019). In fact, many antibiotics have been already found at detectable levels in the Polish water reservoirs and elsewhere (Koniuszewska et al., 2020; Rodríguez-Pérez \& Bajorath, 2020; Szymańska et al., 2019; Rodriguez-Mozaz et al., 2015; Zhang et al., 2020).

The presence of antimicrobial contaminants in water, even at low concentrations, at first may not seem dangerous, but in the long run, a local accumulation of individual antimicrobial substances may occur, e.g. in the bottom sediments of water reservoirs, or in aquatic plants. At low concentrations, antibiotics are being detected both, in the surface and drinking waters. Despite low levels, these drugs are constantly released into the environment, which additionally increases their hazardous potential. Furthermore, their constant presence in a given area affects many generations of microorganisms.

Effluents from municipal wastewater plants contain a mixture of various groups of drugs, including antibiotics. Such mixtures may have a synergistic effect on individual drugs, enhancing their impact on the environment. The presence of antibiotics in waters influences the composition of the microbiome of a given ecological niche: pond, lake or river (Koniuszewska et al., 2020). This may lead to selection of new drug resistance mechanisms in the environment or to enhanced spread of multi-drug resistant strains in water reservoirs. Antibiotics present in municipal wastewater pose a selective pressure, which not only promotes the growth of drug-resistant strains, but also causes a decrease in the number of drug-sensitive strains (Kümmerer et al., 2003).

Surface waters mostly contain drug-sensitive bacteria, however drug-resistant bacteria are also detected in growing amounts. Antibiotic-resistant bacteria have been detected virtually in all water bodies in the world (Manji et al., 2012; Mishra et al., 2018; Kurekci et al., 2017; ElZanfaly, 2015; Azzam et al., 2017; Danner et al., 2019). People who use water bodies for recreational purposes constantly expose their skin and mucous membranes to bacteria which may be potentially antibiotic resistant. These bacteria can be either commensal, environmental or pathogenic strains which may cause infections, including Pseudomonas aeruginosa. On the other hand, drinking water contaminated with potentially pathogenic bacteria may be associated with food poisoning (Ling et al., 2018). The risk of contamination becomes even greater when the bacteria that cause the infections are not susceptible to antibiotics. Worldwide, 700,000 people a year die from bacterial diseases that would be largely curable if the bacteria had not acquired resistance genes (De Oliveira et al., 2020). The number of resistant bacteria is constantly increasing, and according to the World Health Organisation, by 2050 as many as 10 million people a year will have died from infectious diseases caused by drug-resistant microorganisms. The increasing number of people suffering from infectious diseases in areas where sewage treatment plants are unable to disinfect wastewater sufficiently causes in turn large-scale contamination of the environment with drug-resistant microorganisms (WHO Antimicrobial resistance: global report on surveillance 2014).

Despite the fact that cephalosporins are rarely used in hospital and veterinary treatment, the presence of strains resistant to this group of anti-bacterial drugs is an im- portant fact that requires attention (Berendonk et al., 2015). Bacilli of the Enterobacterales family, producing ESBL beta-lactamases (Extended-Spectrum Beta-Lactamases), have been and are still associated with nosocomial infections. Thus, during the 2019-2021 period we sampled 14 retention reservoirs, 12 streams, 3 rivers and 1 lake situated in the Tricity area, Poland, looking for the presence of ESBL strains, which could possibly pose a threat to human health and create a suitable ground for acquiring antibiotics resistance in the natural environment. We have analysed not only their antibiotic resistance patterns, but also phenotypic traits important for bacterial survival in the environment, as well as for their pathogenesis.

\section{MATERIALS AND METHODS}

\section{Water sample collection}

40 water samples were collected in the Pomorskie voivodship (Poland) on 17.06.2019, 30.05.2019, 06.12.2019, 20.03.2020, 21.03.2020, 13.03.2021 and 17.03.2021, from different water reservoirs, such as the retention reservoirs, streams and rivers passing towns (Fig. 1, Supplementary Table 1 at https://ojs.ptbioch.edu.pl/index.php/abp). The water samples were collected into sterile $500-\mathrm{ml}$ glass bottles, 1 meter away (if possible) from the shore of the water reservoirs, about $20 \mathrm{~cm}$ below the surface. Then, the samples were immediately transported to the laboratory in an isothermal box, kept at $4^{\circ} \mathrm{C}$ and processed within $24 \mathrm{~h}$. There are no intensive animal husbandry, slaughterhouses, fish farms or pharmaceutical plants in the vicinity of the studied water reservoirs. However, there are several large hospital centres in the area, although they are not in close vicinity of any of the sampled water reservoirs. In Gdansk, there are 57 retention reservoirs localized at 7 streams. All of the streams flow into the Gulf of Gdansk. Samples were collected from 14 randomly selected retention reservoirs, 3 rivers, 1 lake and 12 streams localized in Gdansk, Gdynia, Sopot, Reda and Puck (Fig. 1, Supplementary Table 1 at https://ojs.ptbioch.edu.pl/index.php/ abp).

\section{Isolation of ESBL strains}

Membrane filtration method (Baird et al., 2017) was used to examine the water samples. $50 \mathrm{~mL}$ samples were passed through sterile filters $(0.22 \mu \mathrm{m}$ pore diameter, Merck, Germany) with the use of a Merck Millipore membrane filtration set. Then, the filters were placed on the Chromagar ESBL medium (Graso Biotech, Poland) and incubated for $17-24 \mathrm{~h}$ at $37^{\circ} \mathrm{C}$. Positive colonies were then counted (pink colonies for the presence of $E$. coli, blue colonies for the presence of Enterobacterales from the KESC group (Klebsiella, Enterobacter, Serratia, Citrobacter), and expressed as CFU/ $100 \mathrm{ml}$ (Colony Forming Units) for each tested water reservoir. For positive plates, at least one colony was transferred onto a fresh medium and grown until pure culture was obtained. Isolated colonies were identified using MALDI-TOF MS (Matrix-Assisted Laser Desorption/Ionization with Time Of Flight Mass Spectrometry) (MALDI Biotyper; Bruker Daltonics, USA) according to the manufacturer's procedure. Isolated colonies were also preserved by growing them in the LB medium (Graso Biotech, Poland) at $37^{\circ} \mathrm{C}$ for $24 \mathrm{~h}(150 \mathrm{rpm})$ and transferring $1 \mathrm{ml}$ of bacterial cultures into $1.5 \mathrm{ml}$ Eppendorf tubes and freezing them at $-60^{\circ} \mathrm{C}$ with $20 \%$ glycerol (Epoch, Poland). 


\section{Antimicrobial Susceptibility Testing}

The double-disk synergy (DDS) assay was carried out to identify ESBL-producing strains (Jarlier et al., 1988). Subsequently, E. coli and KESC isolates were tested using a Kirby-Bauer disk diffusion assay for susceptibility to the following 16 antimicrobial agents according to the European Committee for Antimicrobial Susceptibility Testing (EUCAST) v.10.0 (2020) guidelines (European Committee on Antimicrobial Susceptibility Testing. Breakpoints tables for interpretation of MICs and zones diameters. Version 10.0, 2020, 2020): ampicillin $(10 \mu \mathrm{g})$, amoxicillin/clavulanic acid $(10 / 30 \mu \mathrm{g})$, piperacillin/tazobactam $(30 / 6 \mu \mathrm{g})$, cefuroxime $(30 \mu \mathrm{g})$, ceftazidime $(10 \mu \mathrm{g})$, cefepime $(30 \mu \mathrm{g})$, cefotaxime (5 $\mu \mathrm{g})$, ciprofloxacin $(5 \mu \mathrm{g})$, gentamycin $(10 \mu \mathrm{g})$, amikacin $(10 \mu \mathrm{g})$, imipenem $(10 \mu \mathrm{g})$, meropenem $(10 \mu \mathrm{g})$, ertapenem $(10 \mu \mathrm{g})$, tigecycline $(15 \mu \mathrm{g})$, sulfamethoxazole/trimethoprim $(25 / 25 \mu \mathrm{g})$, cefoxitin $(30 \mu \mathrm{g})$ (Oxoid). E. coli ATCC 25922 (C49) was used as a reference strain (Supplementary Table 2 at https://ojs.ptbioch.edu.pl/index. php/abp).

\section{Enzyme production, motility and biofilm formation assays}

For all enzyme production assays, as well as motility and biofilm formation, the bacterial cultures were freshly streaked on LA medium (Graso Biotech, Poland) and grown at $37^{\circ} \mathrm{C}$ for $24 \mathrm{~h}$. Then, bacterial suspensions were prepared from these fresh cultures in sterile $0.85 \%$ $\mathrm{NaCl}$ and adjusted to $0.5 \mathrm{MacFarland}$ units (DensiCheK plus, Biomeriux). For enzyme and motility assays, $10 \mu \mathrm{l}$ of each bacterial suspension was placed on the medium surface. Protease production was measured on a medium containing skim milk (2 g/l) after incubation for $48 \mathrm{~h}$ at $37^{\circ} \mathrm{C}$ and at $20^{\circ} \mathrm{C}$ (Ji et al., 1987). The ability to produce DNases was assessed on DNase agar plates (Graso Biotech, Poland) after $48 \mathrm{~h}$ of incubation at $37^{\circ} \mathrm{C}$ and flooding the plates with $1 \mathrm{~N} \mathrm{HCl}$ (Sigma Aldrich, Germany). For both tests, the diameter of clear halo around the colonies was measured. All experiments were performed twice, with 4 replicates. To determine the swarming and swimming motility, bacterial strains were inoculated onto $0.8 \%$ and $0.3 \%$ semisolid LA agar plates, respectively, and incubated at $37^{\circ} \mathrm{C}$ and at $20^{\circ} \mathrm{C}$ for $24 \mathrm{~h}$ (Harshey et al., 2003). The diameter of each halo was measured. In some cases, for swimming ability assays, the bacteria had overgrown the plates. In such cases, a $40 \mathrm{~mm}$ diameter was recorded. These tests were performed twice, with 4 replicates for swimming and 6 replicates for swarming motility assessment.

For biofilm formation, bacterial suspensions prepared as described above were $10 \mathrm{x}$ diluted in $1 / 2 \mathrm{LB}$ medium (decreased amount of yeast extract and peptone). The biofilm formation assay was performed as in Nykyri et al. (2013), with some modifications. $1 \mathrm{ml}$ of prepared bacterial culture was inoculated into 24-well Nunclon Delta Surface (Thermo Scientific) plates and kept for $48 \mathrm{~h}$ at $37^{\circ} \mathrm{C}$ and at $20^{\circ} \mathrm{C}$ without agitation. After the incubation period, $\mathrm{OD}_{600}$ of bacterial cultures was measured and the bacterial cultures were removed from the wells. Then, $70 \mu \mathrm{l}$ of $1 \%$ crystal violet solution was added into each well and left for $20 \mathrm{~min}$ without agitation. After incubation, the wells were washed 3 times with $900 \mu \mathrm{l}$ of distilled water. Then, $900 \mu$ l of ethanol (96\%, Sigma Aldrich, Germany) was added into each well and $\mathrm{OD}_{540}$ of each well was measured. For calculations, the $\mathrm{OD}_{540}$ value of the negative control was subtracted from the values obtained for the strains. Negative values obtained after subtraction were set to 0 . The experiment was performed three times with two replicates.

As the reference for the above mentioned assays, E. coli ATCC25922 (C49) and Serratia marcescens KPD102-BA (C19) were used (Supplementary Table 2 at https://ojs.ptbioch.edu.pl/index.php/abp).

\section{DNA fingerprinting}

The genomic DNA from all chosen strains was isolated with the use of Genomic Mini AX Bacteria Kit (A\&A Biotechnology, Poland). The genomic DNA concentration was measured with the use of Epoch Microplate Spectrophotometer (BioTek Instruments) and the chosen strains were analysed using a repetitive-sequencebased rep-PCR with ERIC primers, as described by Versalovic and others (Versalovic et al., 1998). After PCR, $5 \mu \mathrm{l}$ of the products were resolved in $0.8 \%$ agarose gels $(0.5 \times \mathrm{TBE})$ at $50 \mathrm{~V}$ for $2.5 \mathrm{~h}$. After electrophoresis, the band patterns obtained for different strains were compared with the use of GelJ (Heras et al., 2015). Similarity trees were composed with the unweighted pair group method with arithmetic mean (UPGMA) and band difference was set to 1.0. As a reference, E. coli strains C38, C44, C47, C48, C49 and S. marcescens C19 were used for comparative purposes (Supplementary Table 2 at https://ojs.ptbioch.edu.pl/index.php/abp).

\section{Statistical analysis}

The phenotypic assays (biofilm formation, motility) were tested for statistical significance with ANOVA followed by Tuckey post hoc test $(p<0.05)$, with Statistica 13.3 (StatSoft Inc.). The principal component analysis was performed with the use of the Past software to enable global comparisons between the tested groups of strains (Hammer \& Harper, 2001). The heatmap of phenotypic data was created in Python 3.8 (Van Rossum, 2007) with the Seaborn 0.11.1 package (Waskom, 2021) and Pandas 1.2.4 for visualization (McKinney, 2010) with Euclidean distance matrix. The map (Figure 1) was prepared with the Python 3.8.10 Folium package (Python wrapper to leaflet.js maps 1.7.1, https://pythonvisualization.github.io/folium/).

\section{RESULTS}

\section{ESBLs are present in the Tricity waters}

There are 57 retention reservoirs in Gdansk, and more are being designed and built. Due to the 3 geological elevation zones in the city, from depressed areas to the upland in the city, there is a high risk of flooding in case of heavy rainfall, when huge amounts of water flow from the upper terraces of the city towards the Gdansk Bay. Retention reservoirs in Gdansk have a total capacity of approx. $700,000 \mathrm{~m}^{3}$, and are located in cascades on 7 streams. It creates an exceptional system for draining rainwater into the sea, not implemented in other Polish cities (Gdanskie Wody, 2021). During the 2019-2021 period we sampled 14 retention reservoirs, 12 streams, 3 rivers and 1 lake situated in the Tricity area (Poland) searching for the presence of ESBL strains (Fig. 1).

Of these, 19 samples were collected in Gdansk, 10 in Gdynia, 9 in Sopot and 1 each in Puck and Reda (the Plutnica and Reda rivers). Out of the 19 samples collected in Gdansk, 14 came from retention reservoirs, 1 from the Jasien Lake and 4 from streams. In Sopot and Gdynia, the samples were collected from 9 different 


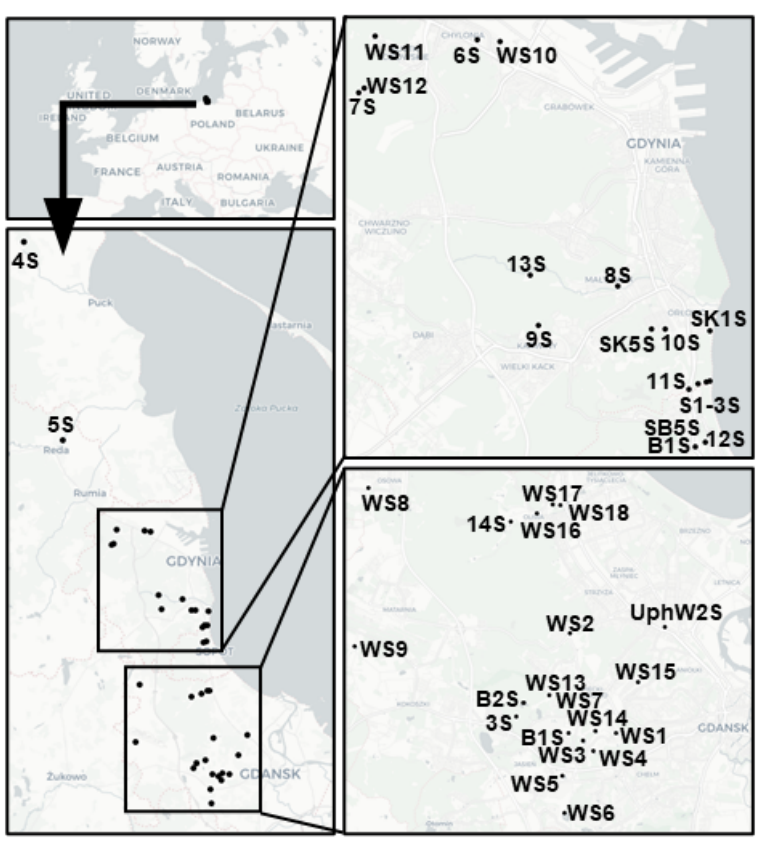

Figure 1. Geographical distribution of the water sampling points (rivers, lakes, streams, retention reservoirs) in the Tricity area (Gdansk, Gdynia, Puck, Reda, Sopot).

For details see Supplementary Table 1 at https://ojs.ptbioch.edu. pl/index.php/abp.

streams and 1 river (the Kacza River in Gdynia) (Supplementary Table 1 at https://ojs.ptbioch.edu.pl/index. $\mathrm{php} / \mathrm{abp})$. In total, among the 40 water samples that were collected, characteristic growth (E. coli and KESC) on the Chromagar ESBL plates was observed for 33 samples (Supplementary Table 1 at https://ojs.ptbioch. edu.pl/index.php/abp). The growth of the colonies characteristic for E. coli was observed in 20 samples, while for the KESC group in 32 samples. Average number of E. coli $\mathrm{CFU} / 100 \mathrm{ml}$ in water samples plated on Chromagar ESBL was $42 \pm 132 \mathrm{CFU} / 100 \mathrm{ml}$, while for the KESC group it was $73 \pm 147 \mathrm{CFU} / 100 \mathrm{ml}$. At two sampling points, WS16 (the Grunwaldzka retention reservoir) and UPH_W2S (Potok Krolewski stream), located in close proximity to each other, high amounts of both - E. coli and KESC group were found (Supplementary Table 1 at https:/ /ojs.ptbioch.edu.pl/index.php/abp). From the perspective of the whole set of data obtained from different sites, there are large differences between the studied cities. For example, for Gdansk, the number of E. coli and KESC group was the highest $(81 \pm 185$ and $130 \pm 200 \mathrm{CFU} / 100 \mathrm{ml}$, respectively), while in Sopot the lowest $(1 \pm 1.4$ and $4 \pm 4 \mathrm{CFU} / 100 \mathrm{ml}$, respectively) (Fig. 2, Supplementary Table 1 at https://ojs.ptbioch. edu.pl/index.php/abp). Intermediary values were observed for Gdynia, Reda and Puck (Fig. 2). On average, the water samples coming from the streams were two times less contaminated with E. coli ESBL and 3 times less contaminated with KESC than the samples from retention reservoirs (Supplementary Table 1 at https://ojs. ptbioch.edu.pl/index.php/abp). The rivers (Kacza, Plutnica, Reda) had very low levels of E. coli ESBL contamination $(0.7 \pm 1.2 \mathrm{CFU} / 100 \mathrm{ml})$, while the load of KESC bacteria was similar to that observed for the streams

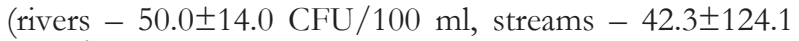
$\mathrm{CFU} / 100 \mathrm{ml}$ ).

Strains with confirmed resistance to cephalosporins were isolated from 33 samples (82.5\%). From a total of 33 positive samples, 56 strains belonging either to $E$.

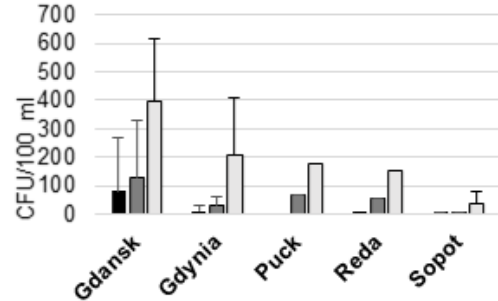

Figure 2. Average amount of ESBL strains detected with the ESBL Chromagar plates in different cities of the Tricity area (Gdansk, Gdynia, Puck, Reda, Sopot), expressed as CFU/100 ml of water sample +/- standard deviation.

Black bars represent ESBL E. coli strains, dark grey bars strains belonging to the KESC group, while light grey bars all other microorganisms able to grow on the medium. For details see Supplementary Table 1 at https://ojs.ptbioch.edu.pl/index.php/abp..

coli or the KESC group were isolated. The species of the isolated strains were identified with MALDI-TOF MS analysis (Table 1, Table 2). The most frequently isolated species were Serratia fonticola (41\%) and Escherichia coli $(21 \%)$. Moreover, $3(5 \%)$ strains of Enterobacter cloacae were isolated, followed by $2(4 \%)$ strains of Citrobacter braakii and Citrobacter freundii each. Only one strain belonging to Enterobacter xiangfangensis was identified, and as many as $11(20 \%)$ strains from the Aeromonas genus were isolated that belonged to 5 different Aeromonas species (Table 1, Table 2).

\section{ESBLs isolated from the Tricity waters present diverse resistance to antibiotics}

For further studies, strains belonging to two of the most representative species, namely S. fonticola and E. coli, were selected (35 isolates, Table 2). All analysed strains were tested for the presence of ESBL beta-lactamases using the DDS phenotypic test. Among the 35 strains tested, 34 were ESBL positive. One negative DDS-test strain (155) showed resistance to all analysed third generation cephalosporins, which may result from the AmpC

Table 1. Number of ESBL strains isolated from the Tricity waters $(n=56)$ belonging to different species, as identified with MALDITOF MS.

\begin{tabular}{lcc}
\hline Species & $\begin{array}{c}\text { Number of iso- } \\
\text { lates }\end{array}$ & $\%$ of isolates \\
\hline Aeromonas bestiarum & 3 & $5 \%$ \\
\hline Aeromonas eucrenophila & 2 & $4 \%$ \\
\hline Aeromonas hydrophila & 2 & $4 \%$ \\
\hline Aeromonas salmonicida & 1 & $2 \%$ \\
\hline Aeromonas veronii & 2 & $4 \%$ \\
\hline Aeromonas spp. & 1 & $2 \%$ \\
\hline Citrobacter braakii & 2 & $4 \%$ \\
\hline Citrobacter freundii & 2 & $4 \%$ \\
\hline Enterobacter cloacae & 3 & $5 \%$ \\
\hline Enterobacter xiangfangensis & 1 & $2 \%$ \\
\hline Escherichia coli & 12 & $2 \%$ \\
\hline Rerratia fonticola & 1 & $2 \%$ \\
\hline
\end{tabular}


Table 2. The ESBL Enterobacterales strains isolated from the Tricity water reservoirs in 2019-2021, identified with MALDI-TOF MS analysis. The strains taken for phenotypic and genotypic analysis are marked in bold.

\begin{tabular}{|c|c|c|c|c|}
\hline Collection ID & Date of collection & City & Water reservoir & Species \\
\hline 127 & 06.12 .2019 & \multirow{25}{*}{ Gdansk } & Zabornia retention reservoir & Escherichia coli \\
\hline 128 & 06.12 .2019 & & Potokowa retention reservoir & Escherichia coli \\
\hline 129 & 06.12 .2019 & & Potokowa retention reservoir & Aeromonas hydrophila \\
\hline 130 & 06.12 .2019 & & Potokowa retention reservoir & Aeromonas veronii \\
\hline 131 & 06.12 .2019 & & Potokowa retention reservoir & Aeromonas hydrophila \\
\hline 150 & 12.03 .2020 & & Oliwa Park retention reservoir & Escherichia coli \\
\hline 151 & 12.03 .2020 & & Grunwaldzka retention reservoir & Escherichia coli \\
\hline 152 & 12.03 .2020 & & Grunwaldzka retention reservoir & Serratia fonticola \\
\hline 153 & 12.03 .2020 & & Wilenska retention reservoir & Serratia fonticola \\
\hline 154 & 12.03 .2020 & & Wilenska retention reservoir & Serratia fonticola \\
\hline 155 & 12.03 .2020 & & Mysliwska retention reservoir & Serratia fonticola \\
\hline 163 & 12.03 .2020 & & Osowa retention reservoir & Enterobacter cloacae \\
\hline 164 & 12.03 .2020 & & Jasien lake & Enterobacter cloacae \\
\hline 165 & 12.03 .2020 & & Jasien lake & Enterobacter xiangfangensis \\
\hline 166 & 12.03 .2020 & & Swietokrzyska retention reservoir & Serratia fonticola \\
\hline 167 & 12.03 .2020 & & Jabloniowa retention reservoir & Aeromonas veronii \\
\hline 168 & 12.03 .2020 & & Jabloniowa retention reservoir & Serratia fonticola \\
\hline 169 & 12.03 .2020 & & Cedrowa retention reservoir & Escherichia coli \\
\hline 170 & 12.03 .2020 & & Labedzia retention reservoir & Escherichia coli \\
\hline 172 & 12.03 .2020 & & Potokowa retention reservoir & Serratia fonticola \\
\hline 173 & 12.03 .2020 & & Zabornia retention reservoir & Escherichia coli \\
\hline 174 & 12.03 .2020 & & Potokowa retention reservoir & Serratia fonticola \\
\hline 182 & 12.03 .2020 & & Oliwa Park retention reservoir & Escherichia coli \\
\hline 876 & 18.03 .2021 & & Siedlicki stream & Serratia fonticola \\
\hline 890 & 18.03 .2021 & & Nowiec stream & Serratia fonticola \\
\hline 156 & 12.03 .2020 & \multirow{16}{*}{ Gdynia } & Cisowska stream & Serratia fonticola \\
\hline 157 & 12.03 .2020 & & Cisowska stream & Enterobacter cloacae \\
\hline 158 & 12.03 .2020 & & Cisowska stream & Serratia fonticola \\
\hline 159 & 12.03 .2020 & & Cisowska stream & Serratia fonticola \\
\hline 160 & 12.03 .2020 & & Chylońska stream & Serratia fonticola \\
\hline 199 & 12.03 .2020 & & Chylonska stream & Serratia fonticola \\
\hline 802 & 18.03 .2021 & & Cisowska stream & Rahnella aquatica \\
\hline 810 & 18.03 .2021 & & Kacza river & Serratia fonticola \\
\hline 845 & 18.03.2021 & & Zrodlo Marii stream & Serratia fonticola \\
\hline 874 & 18.03.2021 & & Zrodlo Marii stream & Citrobacter braakii \\
\hline 877 & 18.03 .2021 & & Chylonska stream & Yersinia mollaretii \\
\hline 886 & 18.03.2021 & & Chylonska stream & Citrobacter braakii \\
\hline 88 & 30.05 .2019 & & Kolibkowski stream & Aeromonass almonicida \\
\hline 89 & 30.05 .2019 & & Kolibkowski stream & Aeromona seucrenophila \\
\hline 90 & 30.05 .2019 & & Kolibkowski stream & Aeromonas bestiarum \\
\hline 811 & 18.03.2021 & & Kolibkowski stream & Serratia fonticola \\
\hline 805 & 18.03 .2021 & \multirow{2}{*}{ Puck } & Plutnica river & Serratia fonticola \\
\hline 809 & 18.03 .2021 & & Plutnica river & Serratia fonticola \\
\hline
\end{tabular}




\begin{tabular}{|c|c|c|c|c|}
\hline 807 & 18.03.2021 & \multirow{4}{*}{ Reda } & Reda river & Citrobacter freundii \\
\hline 842 & 18.03 .2021 & & Reda river & Aeromonas spp. \\
\hline 853 & 18.03.2021 & & Reda river & Citrobacter freundii \\
\hline 863 & 18.03 .2021 & & Reda river & Escherichia coli \\
\hline 86 & 30.05 .2019 & \multirow{9}{*}{ Sopot } & Babidolski stream & Aeromonas eucrenophila \\
\hline 87 & 30.05 .2019 & & Babidolski stream & Aeromonas bestiarum \\
\hline 91 & 30.05 .2019 & & Babidolski stream & Aeromonas bestiarum \\
\hline 102 & 17.06.2019 & & Swelina stream & Escherichia coli \\
\hline 103 & 17.06 .2019 & & Swelina stream & Escherichia coli \\
\hline 104 & 17.06 .2019 & & Swelina stream & Escherichia coli \\
\hline 866 & 18.03.2021 & & Elizy stream & Serratia fonticola \\
\hline 878 & 18.03.2021 & & Babidolski stream & Serratia fonticola \\
\hline 882 & 18.03 .2021 & & Swelina stream & Serratia fonticola \\
\hline
\end{tabular}

beta-lactamase mechanism, however further confirmation is necessary.

All tested E. coli and $S$. fonticola strains were resistant to ampicillin (Supplementary Table 3 at https://ojs.ptbioch.edu.pl/index.php/abp). The analysed E. coli strains were more frequently resistant to more than one tested antibiotic than $S$. fonticola strains (Supplementary Table 3 at https://ojs.ptbioch.edu.pl/index.php/abp). However, one $S$. fonticola strain (155) was resistant to all tested antibiotics apart from tigecycline. This particular strain is of special interest since it was also negative in the DDS test for the presence of ESBL enzymes. Regarding groups of antibiotics, most strains $(19 / 35)$ were resistant to at least one cephalosporin, while 10 strains were also resistant to fluoroquinolones. On the other hand, the most active antibiotic groups against bacteria were tetracycline and aminoglycosides (only 1 and 4 resistant strains, respectively). Similarly, only 5 strains were resistant to carbapenems and betalactams/betalactam inhibitors. Resistance to different third generation cephalosporins was different among the tested E. coli and $S$. fonticola strains. Noteworthy, all $E$. coli and $S$. fonticola strains were resistant to cefuroxime. Among the third generation cephalosporins, the most active against the tested strains was ceftazidime, to which $2(9.1 \%)$ S. fonticola strains, and as many as $7(63.6 \%)$ E. coli strains were sensitive (Fig. 3). The number of $E$. coli strains sensitive to third generation cephalosporins was much higher than that of $S$. fonticola strains. All E. coli strains were resistant to at least one of third generation cephalosporins, while among $S$. fonticola strains only 8 out of 22 showed a similar resistance.

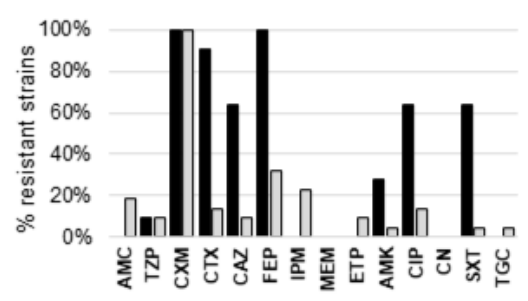

Figure 3. Percentage of $E$. coli (black bars) and S. fonticola (grey bars) strains resistant to different antibiotics.

AMC, amoxicillin/clavulanic acid; TZP, piperacillin/tazobactam; CXM, cefuroxime; CAZ, ceftazidime; FEP, cefepime; CTX, cefotaxime; CIP, ciprofloxacin; CN, gentamycin; AMK, amikacin; IPM, imipenem; MEM, meropenem; ETP, ertapenem; TGC, tigecycline; SXT, trimethoprim/sulfamethoxazole; FOX, cefoxitin
Similarly, the number of E. coli strains resistant to ciprofloxacin and trimethoprim/sulfamethoxazole was much higher (7 strains, $63.6 \%$ ) than the number of $S$. fonticola resistant strains (3 strains, $13.6 \%$ and 1 strain, $4.5 \%$, respectively) (Fig. 3).

The E. coli and $S$. fonticola isolates were most sensitive to carbapenems and especially to meropenem, to which no resistant strains were found (Fig. 3, Supplementary Table 3 at https://ojs.ptbioch.edu.pl/index.php/abp). All E. coli strains were sensitive to imipenem and ertapenem, contrary to $S$. fonticola isolates, where 5 strains $(160,199$, $155,153,166)$ were not sensitive to imipenem and 2 $(155,199)$ were resistant to ertapenem. In this study, the mechanism of lower sensitivity to carbapenems of $S$. fonticola strains was not examined.

Another group of tested antibiotics with high antimicrobial activity were aminoglycosides. Almost all tested strains were sensitive to gentamycin, except for 3 E. coli strains $(127,128,151)$ isolated from two streams and one reservoir in Gdansk, and 1 S. fonticola strain (155) isolated from a reservoir in Gdansk (Supplementary Table 3 at https://ojs.ptbioch.edu.pl/index.php/abp). Similarly, only 1 E. coli strain (170) and $2 S$. fonticola strains $(158,155)$ were resistant to piperacillin/tazobactam, along with 4 other $S$. fonticola strains $(809,199,158,155)$ that were resistant to amoxicillin/clavulanic acid. Among the tested strains, only $S$. fonticola 155 was resistant to all tested groups of antibiotics, while 3 E. coli strains (127, $128,151)$ were resistant to four groups (cephalosporins, aminoglycosides, fluoroquinolones and sulphonamides) of antibiotics.

Comparing isolates from both species, E. coli strains showed a higher incidence of multidrug resistance pattern, as 7 strains $(104,102,127,182,150,128,151)$ were resistant to more than one antibiotic (Supplementary Table 3 at https://ojs.ptbioch.edu.pl/index.php/abp).

\section{E. coli and S. fonticola ESBL strains show large diversity in phenotypic traits}

Not only do the E. coli and S. fonticola strains show differences in antibiotics resistance, but they also present high diversity when looking at phenotypic traits important for pathogenesis and survival in harsh environments, such as motility, biofilm formation and production of extracellular enzymes. For 12 E. coli strains and 23 S. fonticola strains diverse phenotypic tests were performed at two different temperatures $\left(20^{\circ} \mathrm{C}\right.$ and $\left.37^{\circ} \mathrm{C}\right)$ to 
A.

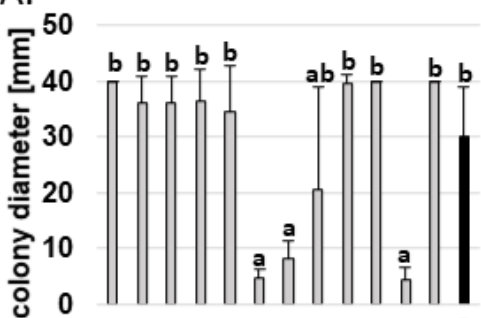

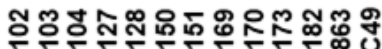

B.

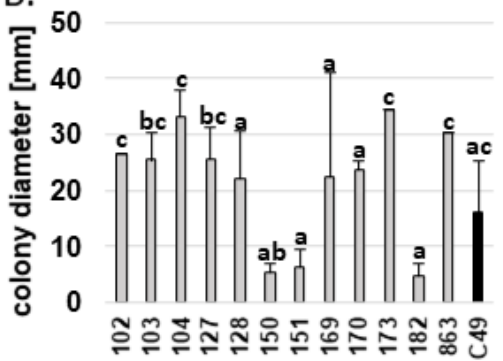

C.

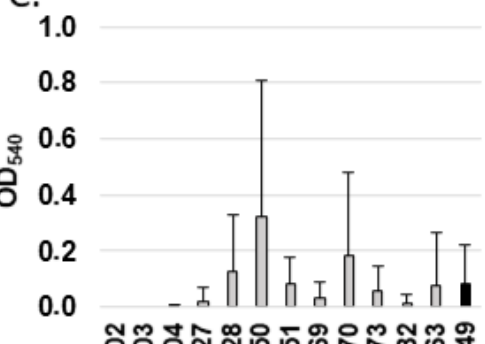

D.

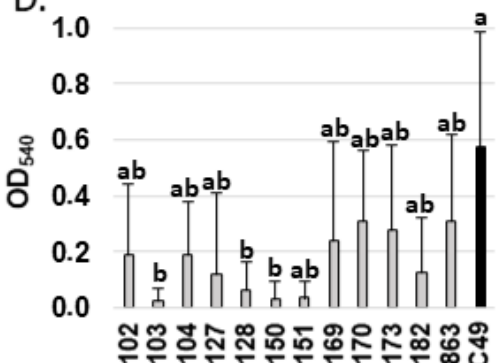

Figure 4. Swimming motility $(A ; B)$ and biofilm formation (C; D) of E. coli ESBL strains isolated from the Tricity water reservoirs tested at $37^{\circ} \mathrm{C}(\mathrm{A} ; \mathrm{C})$ and $20^{\circ} \mathrm{C}(\mathrm{B} ; \mathrm{D})$.

Swimming motility was expressed as an average colony diameter ( $\mathrm{mm}$ ) with standard deviation ( $\mathrm{n}=4$ ), while biofilm formation was expressed as an average $\mathrm{OD}_{540}$ value of crystal violet ethanol extractions after background subtraction, with standard deviation ( $\mathrm{n}=2$ ). Swimming motility was repeated twice, while biofilm formation three times. The results marked with different letters are statistically different as assayed with ANOVA and the Tuckey post hoc test, $p<0.05$.

highlight any differences in the strains' behaviour. None of the strains were able to produce DNases, nor proteases under tested conditions, except for the $S$. marcescens C19 reference strain (not shown). The swarming motility of the strains was similar for both $E$. coli and $S$. fonticola environmental isolates, and was about 3 times lower than the one observed for the $S$. marcescens $\mathrm{C} 19$ reference strain (not shown).

The swimming motility of the E. coli strains was approximately $30 \%$ higher at $37^{\circ} \mathrm{C}$ than at $20^{\circ} \mathrm{C}$ (Fig. 4AB). Only 3 strains presented statistically lower swimming motility $(150,151$ and 182$)$ at $37^{\circ} \mathrm{C}$ than other strains. Strains 150 and 182 where isolated from the same retention reservoir (Oliwa Park), while E. coli 151 was isolated from the Grunwaldzka retention reservoir, in close vicinity to the previous one. At $20^{\circ} \mathrm{C}$, the swimming motility of most $E$. coli environmental isolates was higher than the one observed for E. coli C49, although this was not statistically significant. The ability to form biofilm was higher at $20^{\circ} \mathrm{C}$ than at $37^{\circ} \mathrm{C}$ for most strains except for $E$. coli 151 . Interestingly, at $20^{\circ} \mathrm{C}$ the strains showing low swimming motility also showed low biofilm formation capability $(150,151,182)$ under tested conditions (Fig. 4BD).

When looking at $S$. fonticola strains, they were compared to the $S$. marcescens $\mathrm{C} 19$ reference strain. S. fonticola environmental isolates presented higher swimming motility at $20^{\circ} \mathrm{C}$ than at $37^{\circ} \mathrm{C}$. At $20^{\circ} \mathrm{C}$, the swimming motility for all the $S$. fonticola strains (except for 882) was significantly lower than the one found for $S$. marcescens C19, while at $37^{\circ} \mathrm{C}$ only a few isolates were less motile than the reference strain $(155,172,805,876,890)$ (Fig. 5AB). When looking at biofilm formation capability of $S$. fonticola, it was generally higher at $37^{\circ} \mathrm{C}$ than at $20^{\circ} \mathrm{C}$, while swimming motility was generally higher at $20^{\circ} \mathrm{C}$ than at $37^{\circ} \mathrm{C}$. However, at $37^{\circ} \mathrm{C}$ the strains with low biofilm formation capability also expressed low swimming motility $(152,166,809,810,811,845,866,876,878)$ (Fig. 5AC).
Interestingly, S. fonticola 155, which had low swimming ability at $20^{\circ} \mathrm{C}$, showed high ability to form biofilm under the same conditions.

We also performed a combined principal component analysis (PCA) taking into account all phenotypic tests (swimming, swarming, biofilm formation) and antibiotics resistance for the tested E. coli and $S$. fonticola strains (Fig. 6). By combining all of these data, we could explain $40 \%$ and $27 \%$ of the variance among the strains with component PC1 and PC2, respectively. The E. coli strains seem to form clusters of strains which are more similar to each other, like for example strains 151, 150 and 182 and another cluster of E. coli 102 and 104 which were isolated either from the same retention reservoir or in close vicinity (Fig. 6, Table 2). However, there were also strains clustered with each other but isolated from different water reservoirs, such as E. coli 173 and 863, and E. coli 127 and 128. Contrary to E. coli isolates, S. fonticola isolates did not seem to form any clusters. Most of the strains were grouped together regardless of the place of isolation. Interestingly, there was one $S$. fonticola strain (155), which was highly different from other $S$. fonticola isolates and turned out to be more similar to E. coli isolates when looking at phenotypic traits (Fig. 6). Detailed analysis of phenotypic traits, together with antibiotics resistance, showed that biofilm formation at $37^{\circ} \mathrm{C}$, swarming at both temperatures and resistance to cefuroxime are showing similar trends in the tested group of $S$. fonticola and E. coli strains (Supplementary Fig. 1 at https:// ojs.ptbioch.edu.pl/index.php/abp). Other traits, such as swimming, biofilm formation at $20^{\circ} \mathrm{C}$ and resistance to other antibiotics, form another cluster of features. In a global analysis based on Euclidean distance, some of the E. coli and $S$. fonticola isolates are clustered together. In this case, $S$. fonticola 155 again stands out from the group of strains, showing even more differences from other strains than S. marcescens C19 (Supplementary Fig. 1 at https://ojs.ptbioch.edu.pl/index.php/abp). 
A.

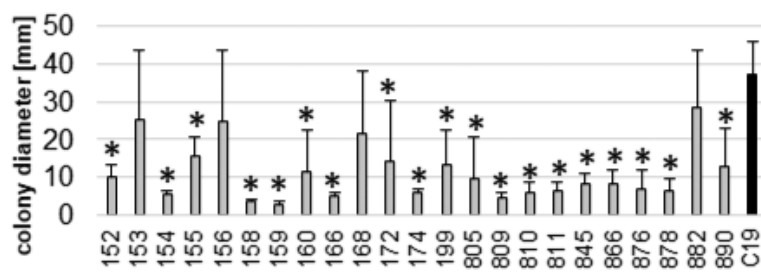

B.

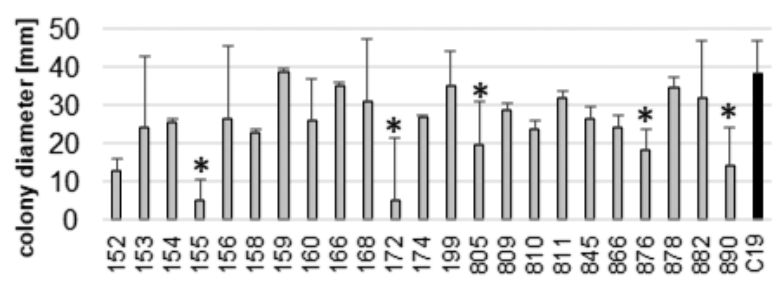

C.

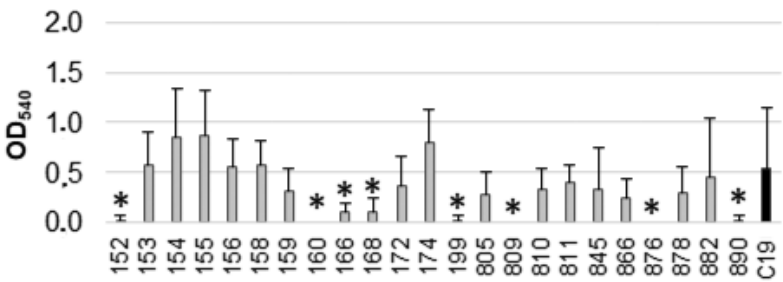

D.

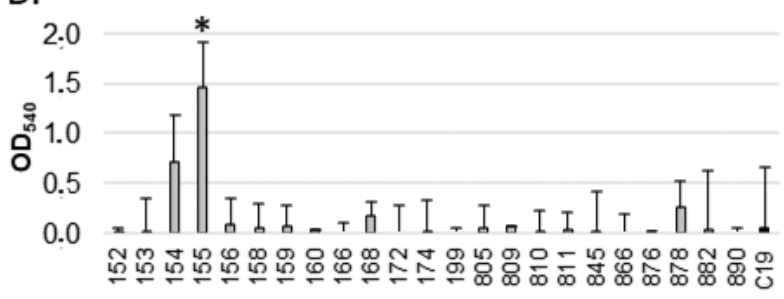

Figure 5. Swimming motility $(A ; B)$ and biofilm formation $(C ; D)$ of S. fonticola ESBL strains isolated from the Tricity water reservoirs tested at $37^{\circ} \mathrm{C}(\mathrm{A} ; \mathrm{C})$ and $22^{\circ} \mathrm{C}(\mathrm{B} ; \mathrm{D})$.

Swimming motility was expressed as an average colony diameter $(\mathrm{mm})$ with standard deviation ( $\mathrm{n}=4)$, while biofilm formation was expressed as an average $\mathrm{OD}_{540}$ value of crystal violet ethanol extractions after background subtraction, with standard deviation ( $\mathrm{n}=2$ ). Swimming motility was repeated twice, while biofilm formation three times. The results marked with an asterisk are statistically different from the reference strain S. marcescens C19 as assayed with ANOVA and the Tuckey post hoc test, $p<0.05$.

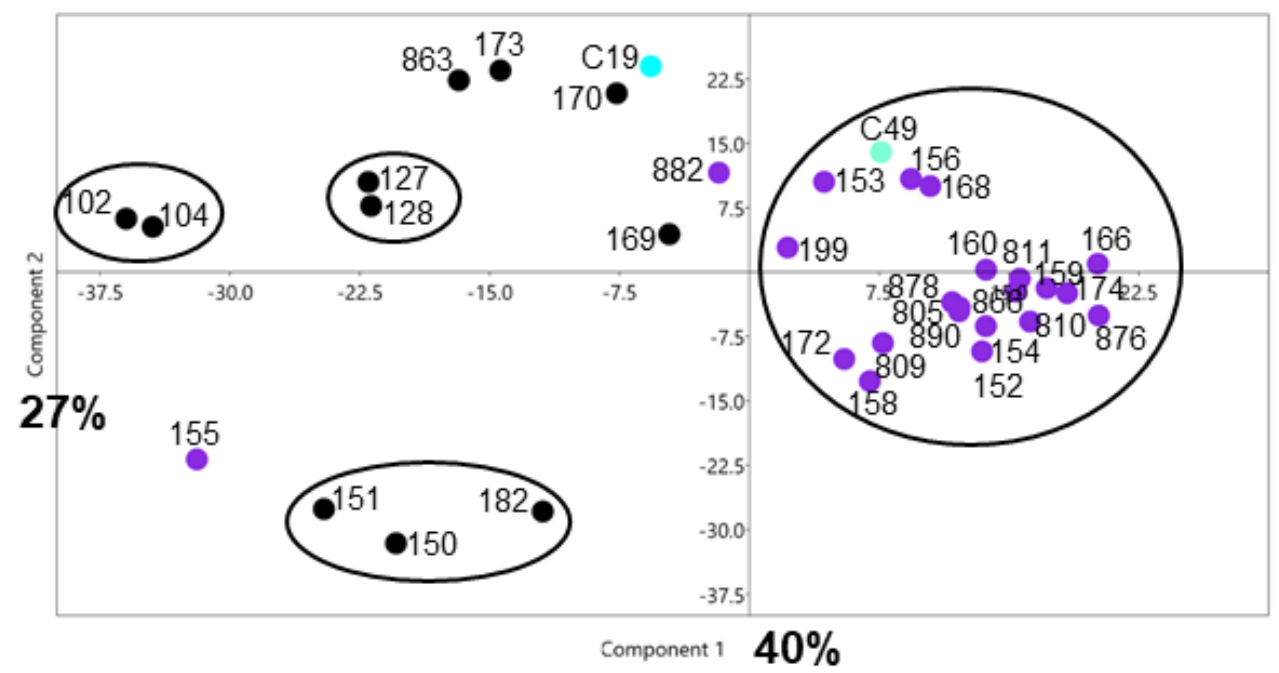

Figure 6. Principal component analysis (PCA) of biofilm formation, swimming and swarming motility, and antibiotics resistance of $S$. fonticola and E. coli ESBL strains. E. coli C49 and S. marcescens C19 were used as a reference.

The biofilm formation and motility assays were performed at $37^{\circ} \mathrm{C}$ and $22^{\circ} \mathrm{C}$. E. coli strains are marked with black dots, while S. fonticola with violet dots.

ESBLs from S. fonticola and E. coli genera isolated from the Tricity waters present diverse fingerprinting profiles

Given a large phenotypic diversity among the isolated E. coli and S. fonticola ESBL strains, it was decided to verify their genotypic relationships. With the use of rep-PCR fingerprinting profiles obtained with ERIC primers, it was possible to assess the genetic variability among the isolated strains (Fig. 7). Two strains (E. coli 103 and $S$. fonticola 845) were excluded from the analysis as their isolated genomic DNA was unstable, preventing appropriate execution of the experiments. When taking into account profiles obtained for E. coli strains, $5 \mathrm{E}$. coli reference strains were used in the analysis that possessed similar or identical profiles forming a separate clade. Another clade was formed by E. coli environmental isolates, which in turn presented unique profiles for each strain (Fig. 7A).

For S. fonticola isolates, similar to E. coli, diversity among obtained rep-PCR profiles could be observed (Fig. 7B). Two S. fonticola strains (153 and 154) isolated from the Wilenska retention reservoir (Gdansk) showed almost the same band patterns, while other strains presented diverse profiles. Still, the strains could be divided into a few clades. However, these clades do not reflect geographical origin nor phenotypic analysis, apart from a few cases. For example, differently from all other strains in the phenotypic analysis, S. fonticola 155 formed a clade with several other strains $(152,153,154,156,159,805,890)$ in the fingerprinting analysis. E. coli strains (150, 151, 182) that prove to be similar in the PCA analysis of the 
A.

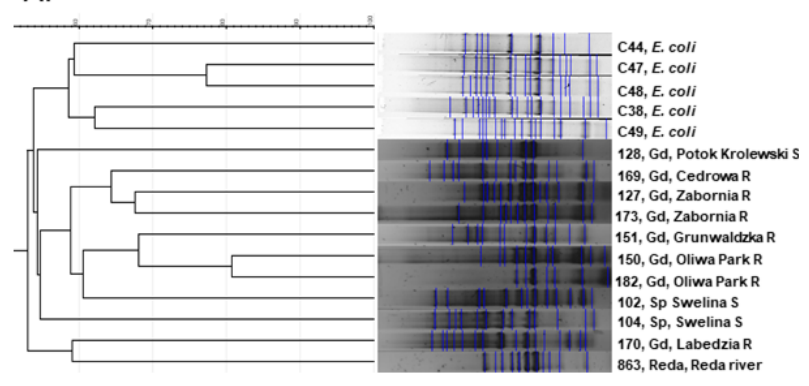

B.

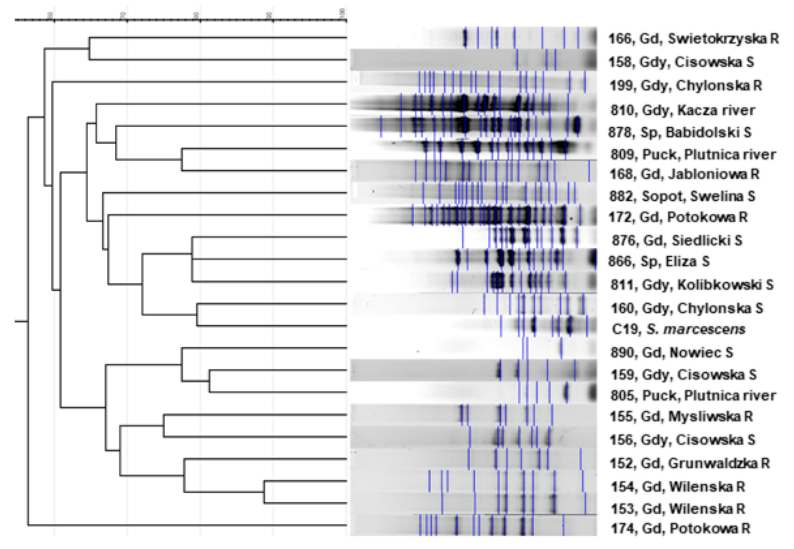

Figure 7. Rep-PCR profiles similarity of E. coli (A) and S. fonticola (B) ESBL strains isolated in the Tricity water reservoirs in 20192021.

The profiles were obtained with ERIC rep-PCR primers and analysed with GelJ software using UPGMA and band similarity index set to 1.0. S. marcescens C19 and E. coli C38, C44, C47, C48, C49, were used as a reference. Gd, Gdansk; Gdy, Gdynia; Sp', Sopot; 'S', stream; ' $R$ ', retention reservoir.

phenotypic traits, also fall in the same clade in the rep-PCR profile analysis. In contrast, E. coli 102 and 104 which are similar in PCA, tend to have very different rep-PCR profiles (Fig. 7A, Fig. 6).

\section{DISCUSSION}

Faecal microorganisms can enter water bodies in diverse ways, including runoff, sewage discharge, and direct faecal deposition (Korajkic et al., 2019). Many investigations have shown the presence of multi-drug resistant coliforms in water (Manji et al., 2012; Mishra et al., 2018; Kurekci et al., 2017; El-Zanfaly, 2015; Azzam et al., 2017). In water reservoirs, such as rivers, streams, lakes and retention reservoirs, both pathogenic and commensal Enterobacterales may be present (Muraleedharan et al., 2019). Pathogenic bacteria present in the water reservoirs may in turn cause infections in humans, which often have to be treated with antibiotics (Manji et al, 2012). The antibiotic therapy is effective when the causative agent is drug-sensitive, otherwise the treatment is much more challenging. Thus, there is a growing concern regarding the occurrence of multi-drug resistance in coliforms which can render antibiotic therapy ineffective (Mishra et al., 2018). Presently, antimicrobial pharmaceuticals are widely used in patient treatment, as well as in treatment of animals. Poland is one of the European Union countries with the highest usage of antibi- otics, reaching as much as 25.87 DID (Defined Daily Doses per 1000 inhabitants per day) in 2015 (OlczakPieńkowska et al., 2017). When regional usage is considered, the Pomorskie Voivodeship was the fourth largest antibiotic user in Poland (26.57 DID). Pharmaceutical residues excreted by treated humans and animals tend to end up in the water reservoirs where they can be a potential selection factor for multi-drug resistance arising in pathogenic, commensal and environmental microorganisms. In this phenomenon, horizontal and lateral gene transfers could be potent mechanisms (Emamalipour et al., 2020).

The inland water catchment area of the Gulf of Gdansk, together with the Vistula River mouth, are important sources of bacterial contamination, including multi-drug resistant strains feeding into the Baltic Sea. In this study, we verified the presence of multiple ESBL species carrying resistance to different groups of antibiotics. Already in 2014, Bartoszewicz and others (Bartoszewicz et al., 2014) reported the presence of antibiotics resistant E. coli strains in the Sopot streams, while Luczkiewicz and others (Luczkiewicz et al., 2010) reported only one E. coli ESBL out of 155 strains isolated from effluent of the water treatment plant in Gdansk. Here, growth of ESBLs strains could be observed in $80 \%$ of samples, with greater load of strains observed in larger water reservoirs, such as the retention reservoirs (Supplementary Table 1 at https://ojs.ptbioch. edu.pl/index.php/abp). In fact, this is a larger number than the one observed in other rivers, streams and retention reservoirs in the territory of Poland. For example, Lenart-Boroń et al. (Lenart-Boroń et al., 2017) reported that $14 \%$ of the isolated E. coli strains were ESBL E. coli in the Białka and Zakopianka rivers (Southern Poland), while at a later date this percentage rose to $20.6 \%$ of ESBL E. coli strains in the Białka river (Lenart-Boron et al., 2020a). On the other hand, no ESBL strains were detected in the Szreniawa river (Lenart-Boron et al., 2020b). Contrary, as many as $37.1 \%$ of E. coli isolates from effluents from a hospital situated in Olsztyn (Poland) belonged to ESBL, while from the city wastewater treatment plant effluents there was only $17.7 \%$ of such strains present (Korzeniewska et al., 2013). In rivers, the load of ESBL bacteria was usually lower than in streams, but the water flow rate of the river is usually less turbulent, which enables deposition of the microorganisms in the sediments with the speed of $0.066 \mathrm{~m} / \mathrm{h}$ (GarciaArmisen et al., 2009). In contrast, streams with more ESBL E. coli than in the rivers, usually have a high flow rate, which can prevent microorganisms from depositing themselves on the way. It is not surprising that in the retention reservoirs much more ESBL strains were found, as these reservoirs are fed by both, the streams and in case of heavy rain also with rain waters flowing from the urban areas. Moreover, the retention reservoirs in Gdansk are rich with birds which can also deposit their faeces contaminated with ESBL strains (B. Rybak, data not published). In fact, already in 2009 , faeces of birds caught in the Tricity area were in $27 \%$ contaminated with ESBL E. coli (Literak et al., 2010). We managed to isolate 56 ESBLs strains out of all of the water reservoirs, the majority of which belonged to E. coli (12) and S. fonticola (23) species.

Within Enterobacterales, strains of the Serratia genus are frequently encountered in the human nosocomial infections. Apart from Serratia marcescens and Serratia liquefaciens complex (S. liquefaciens, Serratia proteamaculans, Serratia grimesii), which are regarded as a major agent causing human Serratia infections, there is little information 
about the remaining species of Serratia ('unusual' serratiae), including their susceptibility patterns to antimicrobial agents or underlying mechanisms of resistance (Grimont et al., 1992). Strains of $S$. fonticola are widespread in the environment (drinking water, sewage and soil), with birds being reported as possible natural hosts (Stock et al., 2003). As a human pathogen, $S$. fonticola has been associated with multiple diseases, such as diarrhoea, septic arthritis, wound, respiratory, urinary tract, bloodstream, or skin and soft tissue infections (Stock et al., 2003). Resistance to beta-lactams in $S$. fonticola has been mediated by chromosomal class A extended-spectrum b-lactamases ESBLs belonging to the FONA family (Philippon et al., 2016; Fuentes-Castillo et al., 2020).

Among the tested E. coli and S. fonticola strains, large differences in resistance to groups of antibiotics could be observed. Strains that belonged to the S. fonticola (except 155) species were rarely resistant to other antibiotic groups except for third generation cephalosporins, contrary to E. coli isolates. Stock and others (Stock et al., 2003) have also pointed out the natural susceptibility of several Serratia species ( $S$. ficaria, S. fonticola, S. odorifera, $S$. plymuthicaand $S$. rubidaea) to a wide range of antimicrobial agents (Stock et al., 2003). S. fonticola strains are naturally sensitive to tetracycline and naturally resistant to ticarcillin and amoxicillin. At the same time, this species is sensitive or intermediately sensitive to aminopenicillins in the presence of $\beta$-lactamase inhibitors. Stock et al. (2003) have shown that their Serratia spp. isolates were able to express their own naturally occurring AmpC $\beta$-lactamase, which might be inducible ( $S$. ficaria, S. fonticola, S. odorifera) or not inducible ( $S$. rubidaea). Interestingly, $S$. fonticola 155 isolated from the Mysliwska retention reservoir (Gdansk) has shown a multi-drug resistant pattern for third generation cephalosporins and at the same time was negative in the DDS-test. Taking into consideration Stockand others (Stock et al., 2003), it seems possible that $S$. fonticola 155 may be facilitated with inducible AmpC $\beta$-lactamase. The unique $\beta$-lactam susceptibility pattern of $S$. fonticola 155 , showing resistance to amoxicillin and several cephalosporins, may be due to expression of a chromosomally encoded class A $\beta$-lactamase with an enhanced cephalosporinase activity, which in case of S. fonticola 155 needs further investigation (Stock et al., 2003). Contrary to S. fonticola, E. coli ESBL isolates were generally more resistant to the tested antibiotics. However, a few $S$. fonticola strains were not sensitive to imipenem, a representative of carbapenems. Carbapenems are considered as antibiotics of the 'last resort', used for treatment of patients infected with drug-resistant pathogens. S. fonticola can harbour its drug resistance to imipenem on a plasmid, which in turn can be disseminated to other microorganisms present in the environment, such as the isolated ESBL E. coli strains. Similarly to $S$. fonticola 155 , it was found that environmental $S$. fonticola UTAD54 was resistant to multiple antibiotics and possessed genes coding for multiple enzymes (A $\beta$-lactamase with carbapenemase activity, carbepenemases SFC-1 and $\mathrm{Sfh}-\mathrm{I})$, which are not common among $S$. fonticola strains (Henriques et al., 2004; Saavedra et al., 2003).

Apart from the antibiotics resistance of the tested $E$. coli and $S$. fonticola strains, closer consideration was taken for other phenotypic features of these bacteria which may facilitate their survival in the water reservoirs, as well as be potential factors enabling efficient pathogenesis. Enzyme production, biofilm formation and motility were investigated at two different temperatures, reflecting both, the host environment $\left(37^{\circ} \mathrm{C}\right)$ and the water environment $\left(20^{\circ} \mathrm{C}\right)$. In general, we noticed differ- ences in biofilm formation ability and swimming motility, which were both species and temperature dependent. Higher swimming motility and lower ability to form biofilm was observed for S. fonticola grown at $20^{\circ} \mathrm{C}$. The E. coli isolates were more motile and produced less biofilm at $37^{\circ} \mathrm{C}$, which may suggest that they are more suited to invade the host than to persist in the environment. Interestingly, $7 \mathrm{E}$. coli isolates, which were more motile at $37^{\circ} \mathrm{C}$, simultaneously produced more biofilm (102, $104,127,169,170,173,863)$, while 2 E. coli strains (103 and 128) were not efficient in biofilm production. This finding is in agreement with Wood and others (Wood et al., 2006) who showed that in some cases E. coli requires motility for biofilm formation in its early stage. Wood and others (Wood et al., 2006) compared motility and biofilm formation of multiple $E$. coli strains which proved to be correlated. The strains capable of producing the largest biofilms under tested conditions were also the most motile (Wood et al., 2006). In the case of $S$. fonticola species, 4 S. fonticola strains $(153,155,156$ and 882) also showed a similar pattern of being more motile and a better biofilm producer at $37^{\circ} \mathrm{C}$. This ability is particularly important because production of biofilms often complicates chronic and difficult-to-treat infections by protecting bacteria from the immune system, decreasing antibiotic efficacy, and dispersing planktonic cells to distant body sites (Jackson et al., 2002).

Due to large diversity among the tested strains regarding their phenotypic traits, such as antibiotics resistance, motility and biofilm formation, their genotypic variability with the use of rep-PCR fingerprinting profiles was analysed. The tested E. coli and S. fonticola ESBL strains presented large diversity of profiles, which are dissimilar from the reference strains used in this study. High variability of rep-PCR profiles of bacteria isolated from water reservoirs is widely documented (Moreira et al., 2012; Potrykus et al., 2016; Khare et al., 2020; Chandrasekaran et al., 2015; Kotlarska et al., 2015; Lenart-Boroń et al. 2020a). Similar results for aquatic E. coli were observed in the Yamuna River (India) (Khare et al., 2020). The isolates were highly diverse at all sampling sites of the river except for the entry site (Delhi at Palla). However, in this site the influence of anthropogenic activities and the pollution was the lowest when compared to other sampling sites. Similar situation was observed in Ontario (Canada), where fingerprinting profiles of periphytic E. coli were variable (Moreira et al., 2012). Moreover, unlike Kon et al. (2007), we have observed diverse rep-PCR profiles even for the isolates coming from the same water reservoir, except for $S$. fonticola 153 and 154. In the case of $S$. fonticola no fingerprinting analysis in the literature had been found for comparison purposes. However, the profiles are as diverse as the E. coli profiles obtained in this study (Chandrasekaran et al., 2015).

To sum up, the water reservoirs situated in the urban Tricity area are a habitat for ESBL Enterobacterales strains and thus can be a source of growing antibiotics resistance of the microorganisms in this area. The antimicrobial resistance (AMR), supported by a vertical and/ or horizontal transfer of antibiotic resistance genes, is a serious public health challenge globally. AMR has been widely associated with pathogens in clinical settings, and it is becoming increasingly recognized that nonclinical environments and nonhuman hosts may also be reservoirs of AMR genes. As a result, constant monitoring of these bacteria (present not only in the water reservoirs but also in drinking water and at bathing areas localized by the Baltic Sea) should be taken under consideration, 
since all of the freshwater reservoirs feed into the Baltic Sea with their waters containing ESBL strains.

\section{Acknowledgements}

We would like to thank Dr. Anna-Karina Kaczorowska from the Collection of Plasmids and Microorganisms, University of Gdansk, Gdansk, Poland, for the donation of the reference strains. Additionally, we would like to thank Dr. Monika Cieszynska-Semenowicz and Dr. Goran Grzinić from the Department of Environmental Toxicology, Medical University of Gdansk, for English language editing, and Vladyslav Redko for help with figure preparation.

\section{REFERENCES}

Azzam MI, Ezzat SM, Othman BA, El-Dougdoug KA (2017) Antibiotics resistance phenomenon and virulence ability in bacteria from water environment. Water Sci 31: 109-121. https://doi. org/10.1016/j.wsj.2017.10.001

Baird RB, Eaton AD, Rice EW, Bridgewater L (2017) Standard Methods for the Examination of $W$ ater and $W$ astewater. 23rd edition. Washington, DC: American Public Health Association

Bartoszewicz,M, Michalska M, Cieszyńska M (2014) Resistance to antibiotics in heterotrophic bacteria as a result of environmental pollution. Med Środ 17: 38-46

Berendonk TU, Manaia CM, Merlin Ch, Fatta-Kassinos D, Cytryn E, Walsh F, Bürgmann $H$, Sørum $H$, Norström M, Pons N, Kreuzinger N, Huovinen P, Stefani S, Schwartz T, Kisand V, Baquero F, Martinez JL (2015) Tackling antibiotic resistance: the environmental framework. Nat Rev Microbiol 13: 310-317. https://doi.org/10.1038/ nrmicro3439

Chandrasekaran R, Hamilton MJ, Wang P, Staley C, Matteson S, Birr A, Sadowsky MJ (2015) Geographic isolation of Escherichia coli genotypes in sediments and water of the Seven Mile Creek - a constructed riverine watershed. Sci Total Environ 538: 78-85. https:// doi.org/https://doi.org/10.1016/j.scitotenv.2015.08.013

European Committee on Antimicrobial Susceptibility Testing. Breakpoints tables for interpretation of MICs and zones diameters. Version 10.0, 2020 (2020) 01-01-2020. https://www.eucast.org

Danner MC, Robertson A, Behrends V, Reiss J (2019) Antibiotic pollution in surface fresh waters: Occurrence and effects. Sci Total Environ 664: 793-804. https://doi.org/10.1016/j.scitotenv.2019.01.406

Duckett S (1999) Ernest Duchesne and the concept of fungal antibiotic therapy. Lancet 354: 2068-2071. https://doi.org/10.1016/S01406736(99)03162-1

ECDC (2015) Antimicrobial resistance surveillance in Europe. https:// www.ecdc.europa.eu/en/publications-data/antimicrobial-resistancesurveillance-europe-2015

El-Zanfaly HT (2015) Antibiotic resistant bacteria: a factor to be considered in safe drinking water. J Environ Prot Sustain Dev 1: 134-143.

Emamalipour M, Seidi K, Zununi Vahed S, Jahanban-Esfahlan A, Jaymand M, Majdi H, Amoozgar Z, Chitkushev LT, Javaheri T, Jahanban-Esfahlan R, Zare P (2020) Horizontal gene transfer: from evolutionary flexibility to disease progression. Front Cell Dev Biol 8: 229

Fuentes-Castillo D, Power P, Cerdeira L, Cardenas-Arias A, Moura Q, Oliveira FA, Levy CE, Gutkind G, Catão-Dias JL, Lincopan N (2020) FONA-7, a novel extended-spectrum $\beta$-lactamase variant of the FONA family identified in Serratia fonticola. Microb Drug Resist 27: 585-589. https://doi.org/10.1089/mdr.2020.0061

Galvin S, Boyle F, Hickey P, Vellinga A, Morris D, Cormican M (2010) Enumeration and characterization of antimicrobial-resistant Escherichia coli bacteria in effluent from municipal, hospital, and secondary treatment facility sources. Appl Environ Microb 76: 4772-4779. https://doi.org/10.1128/AEM.02898-09

Garcia-Armisen T, Servais P (2009) Partitioning and fate of particleassociated E. coli in river waters. W ater Environ Res 81: 21-28

Gdańskie Wody (2021) Management of rainwater in Gdansk. http:/ www.gdmel.pl/dla-mieszkancow/zagospodarowanie-wod-opadowych-w-gdansku (in Polish)

Grimont, F. Grimont PAD (1992) The genus Serratia. In: In The Prokaryotes. A Handbook on the Biology of Bacteria: Ecophysiology, Isolation, Identification, Applications. pp 2822-2848. New York, NY, USA: Springer.

Hammer Ø, Harper RP (2001) Past: Paleontological statistics software package for education and data analysis. Palaeontol Electron 4: 9

Harshey RM (2003) Bacterial motility on a surface: many ways to a common goal. Annu Rev Microbiol 57: 249-273. https://doi. org/10.1146/annurev.micro.57.030502.091014

Henriques I, Moura A, Alves A, Saavedra MJ, Correia A (2004) Molecular characterization of a carbapenem-hydrolyzing class A beta-lactamase, SFC-1, from Serratia fonticola UTAD54. Antimicrob Agents
Chemother 48: 2321-2324. https://doi.org/10.1128/AAC.48.6.23212324.2004

Heras J, Domínguez C, Mata E, Pascual V, Lozano C, Torres C, Zarazaga M (2015) Gell-a tool for analyzing DNA fingerprint gel images. BMC Bioinformatics 16: 270. https://doi.org/10.1186/s12859015-0703-0

Hutchings MI, Truman AW, Wilkinson B (2019) Antibiotics: past, present and future. Curr Opin Microbiol 51: 72-80. https://doi. org/10.1016/j.mib.2019.10.008

Jackson DW, Suzuki K, Oakford L, Simecka JW, Hart ME, Romeo $T$ (2002) Biofilm formation and dispersal under the influence of the global regulator CsrA of Escherichia coli. I Bacteriol 184: 290-301. https://doi.org/10.1128/JB.184.1.290-301.2002

Jarlier V, Nicolas MH, Fournier G, Philippon A (1988) Extended broad-spectrum beta-lactamases conferring transferable resistance to newer beta-lactam agents in Enterobacteriaceae: hospital prevalence and susceptibility patterns. Rev Infect Dis 10: 867-878. https://doi. org/10.1093/clinids/10.4.867

Ji J, Hugouvieux-Cotte-Pattat N, Robert-Baudouy J (1987) Use of Mulac insertions to study the secretion of pectate lyases by Erwinia chrysanthemi. Microbiology 133: 793-802

Khare N, Kaushik M, Martin JP, Mohanty A, Gulati P (2020) Genotypic diversity in multi-drug-resistant $E$. coli isolated from animal feces and Yamuna River water, India, using rep-PCR fingerprinting. Environ Monit Assess 192: 681. https://doi.org/10.1007/s10661-02008635-1

Kon T, Weir SC, Howell ET, Lee H, Trevors JT (2007) Genetic relatedness of Escherichia coli isolates in interstitial water from a Lake Huron (Canada) beach. Appl Environ Microbiol 73: 1961-1967. https:// doi.org/10.1128/AEM.02437-06

Koniuszewska I, Korzeniewska E, Harnisz M, Kiedrzyńska E, Kiedrzyński M, Czatzkowska M, Jarosiewicz P, Zalewski M (2020) The occurrence of antibiotic-resistance genes in the Pilica River, Poland. Ecobydrol Hydrobiol 20: 1-11. https://doi.org/https://doi. org/10.1016/j.ecohyd.2019.09.002

Korajkic A, Wanjugi P, Brooks L, Cao Y, Harwood VJ (2019) Persistence and Decay of Fecal Microbiota in Aquatic Habitats. Microbiol Mol Biol Rev 83: e00005-19. https://doi.org/10.1128/ MMBR.00005-19

Korzeniewska E, Korzeniewska A, Harnisz M (2013) Antibiotic resistant Escherichia coli in hospital and municipal sewage and their emission to the environment. Ecotox Environ Safe 91: 96-102. https:// doi.org/10.1016/j.ecoenv. 2013.01.014

Kotlarska E, Luczkiewicz A, Pisowacka M, Burzyński A (2015) Antibiotic resistance and prevalence of class 1 and 2 integrons in Escherichia coli isolated from two wastewater treatment plants, and their receiving waters (Gulf of Gdansk, Baltic Sea, Poland). Environ Sci Pollut Res 22: 2018-2030. https://doi.org/10.1007/s11356-014-3474-7

Kozińska A, Sitkiewicz I (2017) "New" and "old" antibiotics - mechanisms of action and strategies for antimicrobial drugs searching. Kosmos 66: 109-124 (in Polish)

Kümmerer K (2003) Significance of antibiotics in the environment. J Antimicrob Chemoth 52: 5-7. https://doi.org/10.1093/jac/dkg293

Kümmerer K (2009a) Antibiotics in the aquatic environment - A review - Part I. Chemosphere 75: 417-434. https://doi.org/10.1016/J. CHEMOSPHERE.2008.11.086

Kümmerer K (2009b) Antibiotics in the aquatic environment - A review - Part II. Chemosphere 75: 435-441. https://doi.org/10.1016/J. CHEMOSPHERE.2008.12.006

Kurekci C, Aydin M, Yipel M, Katouli M, Gündoğdu A, Jutkina J, Marathe NP, Flach C-F, Larsson DGJ, Madec J-Y, Haenni M, Ponsin C, Kieffer N, Rion E, Gassilloud B, Al-Agamy MH, Shibl AM, Hafez MM, Al-Ahdal MN, Memish ZA (2017) Characterization of extended spectrum $\beta$-lactamase (ESBL)-producing Escherichia coli in Asi (Orontes) River in Turkey. J Water Health 15: 788-798. https:// doi.org/10.2166/wh.2017.257

Lenart-Boroń A (2017) Antimicrobial resistance and prevalence of extended-spectrum beta-lactamase genes in Escherichia coli from major rivers in Podhale, southern Poland. Int J Environ Sci Technol 14: 241250.https://doi.org/10.1007/s13762-016-1155-4

Lenart-Boroń A, Prajsnar J, Guzik M, Boroń P, Chmiel M (2020a) How much of antibiotics can enter surface water with treated wastewater and how it affects the resistance of waterborne bacteria: A case study of the Białka river sewage treatment plant. Environ Res 191: 110037.https://doi.org/10.1016/j.envres.2020.110037

Lenart-Boroń A, Kulik K, Jelonkiewicz E (2020b) Antimicrobial resistance and ESBL genes in E. coli isolated in proximity to a sewagetreatment plant. J Environ Scie Heal A 55: 1571-1580. https://doi.org /10.1080/10934529.2020.1826774

Ling F, Whitaker R, LeChevallier MW, Liu WT (2018) Drinking water microbiome assembly induced by water stagnation. ISME J 12: 1520-1531. https://doi.org/10.1038/s41396-018-0101-5

Literak I, Dolejska M, Janoszowska D, Hrusakova J, Meissner W, Rzyska H, Bzoma S, Cizek A (2010) Antibiotic-resistant Escherichia coli bacteria, including strains with genes encoding the extendedspectrum beta-lactamase and QnrS, in waterbirds on the Baltic Sea 
Coast of Poland. Appl Environ Microb 76: 8126-8134. https://doi. org/10.1128/AEM.01446-10

Luczkiewicz A, Jankowska K, Fudala-Książek S, Olańczuk-Neyman K (2010) Antimicrobial resistance of faecal indicators in municipal wastewater treatment plant. Water Res 44: 5089-5097. https://doi. org/10.1016/j.watres.2010.08.007

Manji PL, Antai SP, Jacob IO (2012) Incidence of Staphylococcus aureus, coliforms and antibiotic resistant strains of Escherichia coli in rural water supplies in Calabar South Local Government Area. J Public Heal Epidemiol 4: 230-237. https://doi.org/10.5897/JPHE12.055

Mishra M, Arukha AP, Patel AK, Behera N, Mohanta TK, Yadav D (2018) Multi-drug resistant coliform: water sanitary standards and health hazards. Front Pharmacol 9: 311

McKinney W (2010) Data structures for statistical computing in python. In Proceedings of the 9th Python in Science Conference 445: 51-56

Moreira S, Brown A, Ha R, Iserhoff K, Yim M, Yang J, Liao B, Pszczolko E, Qin W, Leung KT (2012) Persistence of Escherichia coli in freshwater periphyton: biofilm-forming capacity as a selective advantage. FEMS Microbiol Ecol 79: 608-618. https://doi.org/10.1111/ j.1574-6941.2011.01244.x

Muraleedharan C, Talreja D, Kanwar M, Kumar A, Walia SK (2019) Occurrence of extended-spectrum $\beta$-lactamase-producing bacteria in urban Clinton River habitat. J Glob Antimicrob Resist 16: 225-235. / https://doi.org/10.1016/j.jgar.2018.10.007

Nykyri J, Mattinen L, Niemi O, Adhikari S, Kõiv V, Somervuo P, Fang X, Auvinen P, Mäe A, Palva ET, Pirhonen M (2013) Role and regulation of the Flp/Tad pilus in the virulence of Pectobacterium atrosepticum SCRI1043 and Pectobacterium wasabiae SCC3193. PLoS One 8: e73718-e73718. https://doi.org/10.1371/journal.pone.0073718

Olczak-Pieńkowska A (2017) Consumption of antibiotics in 2010-2015 in primary healthcare in Poland. Updates of the national antibiotic protection program 1/2017 (in Polish)

De Oliveira DMP, Forde BM, Kidd TJ, Harris PNA, Schembri MA, Beatson SA, Paterson DL, Walker MJ (2020) Antimicrobial resistance in ESKAPE pathogens. Clin Microbiol Rev 33: e00181-19. https://doi.org/10.1128/CMR.00181-19

Philippon A, Slama P, Dény P, Labia R (2016) A structure-based classification of class a $\beta$-lactamases, a broadly diverse family of enzymes. Clin Microbiol Rev 29: 29-57. https://doi.org/10.1128/ CMR.00019-15

Potrykus M, Golanowska M, Sledz W, Zoledowska S, Motyka A, Kolodziejska A, Butrymowicz J, Lojkowska E (2016) Biodiversity of Dickeya spp. isolated from potato plants and water sources in temperate climate. Plant Dis 100: 408-417. https://doi.org/10.1094/ PDIS-04-15-0439-RE

Rodriguez-Mozaz S, Chamorro S, Marti E, Huerta B, Gros M, Sànchez-Melsió A, Borrego CM, Barceló D, Balcázar JL (2015) Occurrence of antibiotics and antibiotic resistance genes in hospital and urban wastewaters and their impact on the receiving river.
Water Res 69: 234-242. https://doi.org/https://doi.org/10.1016/j. watres.2014.11.021

Rodríguez-Pérez R, Bajorath J (2020) Interpretation of machine learning models using shapley values: application to compound potency and multi-target activity predictions. I Comput Aided Mol Des 34: 1013-1026. https://doi.org/10.1007/s10822-020-00314-0

Van Rossum G (2007) Python Programming Language. In USENIX annual technical conference 41: 36

Saavedra MJ, Peixe L, Sousa JC, Henriques I, Alves A, Correia A (2003) Sfh-I, a subclass B2 metallo-beta-lactamase from a Serratia fonticola environmental isolate. Antimicrob Agents Chemother 47: 2330_ 2333. https://doi.org/10.1128/AAC.47.7.2330-2333.2003

Stock I, Burak S, Sherwood KJ, Grüger T, Wiedemann B (2003) Natural antimicrobial susceptibilities of strains of 'unusual' Serratia species: S. ficaria, S. fonticola, S. odorifera, S. plymuthica and S. rubidaea. J Antimicrob Chemother 51: 865-885. https://doi.org/10.1093/jac/ dkg156

Szymańska U, Wiergowski M, Sołtyszewski I, Kuzemko J, Wiergowska G, Woźniak MK (2019) Presence of antibiotics in the aquatic environment in Europe and their analytical monitoring: Recent trends and perspectives. Microchem J 147: 729-740. https://doi.org/https:// doi.org/10.1016/i.microc.2019.04.003

Tan SY, Tatsumura Y (2015) Alexander Fleming (1881-1955): Discoverer of penicillin. Singap Med J 56: 366-367. https://doi. org $/ 10.11622 /$ smedi.2015105

Thanner S, Drissner D, Walsh F, Baquero F (2016) Antimicrobial resistance in agriculture. MBio 7: e02227-15. mBio https://doi. org $/ 10.1128 / \mathrm{mBio} .02227-15$

Waskom M (2021) Seaborn: statistical data visualization. J Open Source Software 6: 3021

WHO (2014) Antimicrobial resistance: global report on surveillance 2014 summary, No. WHO/HSE/PED/AIP/2014.2

Versalovic J, de Bruijn FJ, Lupski JR (1998) Repetitive sequencebased PCR (rep-PCR) DNA fingerprinting of bacterial genomes. In Bacterial Genomes 437-454. Springer, Boston, MA. https://doi. org/10.1007/978-1-4615-6369-3_34

Wood TK, González Barrios AF, Herzberg M, Lee J (2006) Motility influences biofilm architecture in Escherichia coli. Appl Microbiol Biotechnol 72: 361-367. https://doi.org/10.1007/s00253-005-0263-8

Zhang G, Lu S, Wang Y, Liu X, Liu Y, Xu J, Zhang T, Wang Z, Yang $Y$ (2020) Occurrence of antibiotics and antibiotic resistance genes and their correlations in lower Yangtze River, China. Environ Pollut 257: 113365 https://doi.org/10.1016/j.envpol.2019.113365

Zhi S, Banting G, Stothard P, Ashbolt NJ, Checkley S, Meyer K, Otto S, Neumann NF (2019) Evidence for the evolution, clonal expansion and global dissemination of water treatment-resistant naturalized strains of Escherichia coli in wastewater. Water Res 156: 208-222. https://doi.org/10.1016/j.watres.2019.03.024 